\title{
Internet Addiction As Correlates To Depression and Life Satisfaction
}

\author{
Christ Michael C. Entienza ${ }^{a}$
}

Article History: Received: 10 November 2020; Revised 12 January 2021 Accepted: 27 January 2021; Published online: 5 April 2021

\begin{abstract}
Common behavioral problem described as an impulse control disorder which doesn't include the use of an intoxicating drug very similar to pathological, is known as Internet Addiction, a rampant disorder during the digital age. This study looked into the relationship of internet addiction towards depression and life satisfaction. Two hundred respondents from various courses of a State University were chosen using fishbowl sampling. The Philippine Student Health Questionnaire was administered and $100 \%$ test results were retrieved. Results showed that most of the respondents are average users. There are also significant numbers who are problematic and the least were excessive users. Most respondents were suffering from mild depression and worryingly there were respondents having moderately severe and severe depression. For life satisfaction, results shows that most respondents are satisfied while some reported that they are slightly satisfied and least reported are dissatisfied. Statistics showed that there is no significant correlation between internet addiction and life satisfaction; however, there is a positive correlation between internet addiction and depression. Results highly suggests exerting efforts for awareness in regulating proper usage of internet such as time management. For Life Satisfaction, it is suggested to continue and share lifestyle practices which contribute to satisfaction and work on areas that need improvement promoting better life satisfaction.

Keywords: internet addiction, depression, life satisfaction
\end{abstract}

\section{Introduction}

Thedawnofthe $21^{\text {st }}$ centurybecameaturningpointinthehistoryandthewayof life. This era welcomed the Fourth Industrial Revolution also known as the Digital Revolution that has a great impact on every aspect of human life. This fourth revolution is a mix of technologies which is bridging the gap between the physical, digital and biological areas. The Industrial Revolution also greatly influenced the way of living of peoplespecificallytheyounggenerationalsoknownasGenZ.Thisgenerationisinternet

savvyandtheyliterallygrewupwiththeInternetaspartoftheirlives(Cheung,McCarty \& Wong 2017). Particularly, the Internet took the center stage which enhanced and changed the way we connect with one another across generations from baby boomers to gen $\mathrm{z}$ and across culture, almost everything is one click away. In Asia, there are billions of Internet users which amount to $46 \%$ of the total population in the internet world (ADMA,2015).Ranking6 ${ }^{\text {th }}$ inAsiaandin $2^{\text {nd }}$ SoutheastAsia,thePhilippineshasover

\section{2 million users which is expected to double (Persaud, 2017)}

The Internet paved the way for convenience, easy access to information and connectivity.Itbrokebordersincommunicationsuchasthosefamilieswhoareseparated by great distance due to work, even helping to find lost relations, made financial transactionseasierandcalibratedprocessesthatgenerallyprovidedconvenience,toname a few. In the academe, internet and connectivity helped research and other student academic concerns as it provided vast data sources on various topics not having to go to several libraries to browse books and get little content. One click offers a range of referenceswithminimumeffortandtimeconsumption. AsmuchastheInternetprovided faster avenues, this also came with undesirable impact, distinctively on behavior and mentalhealth.Excessiveamountoftimewasobservedbeingusedonsocialmedia,games and pornography. As reported by Rappler (2016), Filipino millenials are the top most users of internet who, above all others wants to stay connected and get real-time updates spending5.2 hours (desktop and tablets) and 3.2 hours (mobile). Spending so much time on the Internet also showed alarming negative influences to the youth as study showed that excessive users tended to be anxious, depressed and get into fights often (Goel, Subramanyam\& Kamath2013).

In response to the growing misconducts in using the Internet, the Philippines passedRA10175, oritsCybercrimePreventionActlast2012hopingtospreadawareness, security, and prevention and come down on those using the internet in devious ways. As fortheUniversity,ittakesmeasuresinitsvisionofbecomingthePremierCampusinthe Region promoting quality and responsive academic programs achieving this through productive educational innovations and good governance, of which results of this study can contribute to. Guided likewise by its Mission in consonance with the 
University's philosophy that affirms and avows itself to be a major instrument for the development of the citizenry and the enhancement of nation building by providing quality education and producing seasoned individuals who are highly employable, productive, socially responsible and competent professionals. Supporting the University's research agendaof socialandculturaldevelopmentofitsstakeholders,specificallyHumanDevelopmentand SocialProtection,PublicPersonnelManagementanddevelopment,SocialWelfareisone of the aim goals to be accomplished by thisresearch.

What schools can do is to help prevent and moderate the overuse and misuse of the internet, which is, to put it briefly, called Internet Addiction. Griffith (2008, as citedby Goel, Subramanyam, \& Kamath, 2013) defined it as a subset of behavior addiction that meets the six core components of addiction; tolerance, salience, withdrawal, mood modification, conflict, and relapse. Young, as cited in Waldo (2014), stated that internet addiction is like pathological disorders having impulse-control disorder excludes intoxicant. Shapira, as cited in Bastani (2008) suggested that, it may be a different form ofobsessivecompulsivedisorder.Despitelackingacommondefinition,mostresearchers looktowardsexcessiveandunfettereduseoftheinternetusingcertainapplicationsonline, leadingtoproblematichours(Frangos,Frangos, \&Sotiropoulos,2011).Tragicnumerous headline had captured the attention of the public that is in relation to compulsive internet use Wallace (2015). Goel, Subramanyam, and
Kamath
(2013)
stated
that
while
the

internetisusedbysometoseekinformation,facilitateresearch,businesstransactionsand

interpersonalcommunication,othersuseitfortoomuchgaming,pornography,extensive

hourschatting,andgambling.Meanwhile,Whisman(2015)alsomentionedthatgiventhe pervasive nature of technology, likewise the internet in present society, loss of control is widespread and may result to negative impacts on daily life function, peer and family interactions, academic performance and psychological wellbeing in general. Moreover, peoplewhospendmuchtimeontheinternetissubjecttofeelingsofisolationthatcauses mood declines and low life satisfaction given the nature of online activitiesas performed in solitude and potentially removes interactive social activities (Lissitsa \& Chachashvili- Bolotin, 2015). Additionally, compulsive internet use were reported by researchers, reflecting internet addiction, and dependent on internet, pathological or problematic use, and related to lower psychological mental state. Further, there are suggestions that there couldbesomerelationshipwiththeuseofinternetanddepression.Oneofthemisatwo- year longitudinal study conducted by Young and Kraut (Valiputhenpurayil, 2005) who investigated 169 people on 73 households regarding the effects of internet on social involvement and psychological health and one of their major findings was that using the internet exhibits increase in loneliness anddepression.

Clearly this is a present-day and developing phenomenon and few studies have been made locally. Which is why this study explored the level of Internet addiction in a State University in the Philippines as these are uncommon studies and only concentrated on the Urban areas and to correlate Internet Addiction with Depression and Life satisfaction. Specifically, it answered the questions, (1) What is the level ofinterne2810

addiction of the respondents (2) What is the level of depression of the respondents (3) What is the level of life satisfaction of the respondents (4) Is there a significant relationshipbetweeninternetaddictionanddepression(5)istheasignificantrelationship between internet addiction and lifesatisfaction.

\section{Method}

The study utilized a descriptive-correlation method wherein practices and beliefs that prevail were described and relationships were determined. Cluster sampling was employedtogather200respondentsfromnineprogramsintheuniversity,majorsinclude social sciences making up $49.50 \%$, engineering with $37.50 \%$ and Industrial having $13 \%$. Year level ranges from First year to Fifth year. Respondents' age, ranges from 16 to 24 years old, and sex is a combination of boys being, $40 \%$ and girls, $60 \%$. Most came from middle economic level making up $86.50 \%$, and least were from low having only $4 \%$. Respondents were briefed and assured of treating the data with highest confidentiality. The study utilized and administered the Philippine University Student Health Survey - a 4 part questionnaire having total of 43 items that uses likert scale. This instrument acquires demographics, and measures the levels of Internet Addiction as average, problematic or excessive users, having strong internal consistency (Cronbach's $\alpha=.93$ ) and has 20 items. Depression with Cronbach alphas of .86 and .89 which can classifies minimal, mild, moderate, moderately severe levels having 10 items and Life Satisfaction showed good internal consistency $(\alpha=0.74)$ having 5 items which classifies Extremely satisfied, satisfied, slightly satisfied, Neutral, Slightly dissatisfied and dissatisfied levels. The administration garnered a $100 \%$ return; afterwards post survey was conducted to verify the results of the study. The gathered data were checked; tabulated, analyzed, and interpreted using frequency, percentage and the Pearson-R for the correlation of the variables 


\section{Result}

Level of Internet Addiction of the Respondents Table 1

\begin{tabular}{|l|c|c|c|}
\hline \multicolumn{1}{|c|}{ Score } & Internet Addiction & Frequency & Percentage (\%) \\
\hline 49 and below & Average & 143 & 71.50 \\
\hline $50-79$ & Problematic & 55 & 27.50 \\
\hline $80-100$ & Excessive & 2 & 1.00 \\
\hline \multicolumn{2}{|r|}{ Total } & $\mathbf{2 0 0}$ & $\mathbf{1 0 0 . 0 0}$ \\
\hline
\end{tabular}

As shown in Table 1, most of the respondents are average internet users suggesting that they surf the internet a bit too long sometimes but they have control over their usage. Next significant were identified as problematic, suggesting that they are

Jurnal The Messenger, Vol. ..., No. ..., January or July 20.., pp. ...-...

experiencingoccasionalorfrequentproblemsbecauseoftheInternetandshouldconsider theirfullimpactontheirlives, theleastwereexcessive, andalthoughtheyarethesmallest, these respondents are having significant problems in their lives due to internet usage and should elevate the impact of the Internet in their lives and address problems directly causedbyit.SomewhatsimilartoMakandcolleagues(2014)whofoundthatproblematic internet usage was prevalent in Philippines in the urban areas, these suggest that problematic users are moderately present as well in rural areas, and that if not dealt with early, could lead to excessive. This is most probably due to the nature of fillennials to be engageinwhatisthemarkoftheirgeneration, whichistheinternet,alsohighlyavailable intheruralareas.Moreover,itiscomparablewithBahtandcolleagues(2015)whofound outthat $41.53 \%$ werefoundmildoninternetaddictionandherewehave $71.5 \%$ ofaverage users. The problematic users are found to be using the internet longer than intended that leads to neglecting of self-management and lead to the suffering of personal and social relationships. Excessive are even worse that not only personal and social relationships suffer,buttheyexperiencelosingsleepandhavefeelingsofanxietyanddepressionwhen not in access. Although in rural areas, these fillennial students have access to internet as well, thus, equal chance ofexposure.

Level of Depression of the Respondents Table 2

\begin{tabular}{|c|c|c|c|}
\hline Score & Depression & Frequency & Percentage (\%) \\
\hline $0-4$ & Minimal & 31 & 15.50 \\
\hline $5-9$ & Mild & 101 & 50.50 \\
\hline $10-14$ & Moderate & 54 & 27.00 \\
\hline $15-19$ & Moderately Severe & 12 & 6.00 \\
\hline $20-27$ & Severe & 2 & 1.00 \\
\hline \multicolumn{2}{|r|}{ Total } & 200 & 100.00 \\
\hline
\end{tabular}

Table 2 illustrates that majority of the Fillennials respondents have mild depression making up 50.50 percent of the respondents. They may not need serious treatmentbutshouldwatchoutfortheirpsychologicalwellbeing.Notablealsoarethose with severe level having the least percentage, which warrants treatment for depression, mayuseantidepressant,psychotherapyoracombinationofboth.Coincidingwiththetrend of Baht and Kawa's (2015) study who found out that students $42.31 \%$ were found lowondepression, whereas $38.46 \%$ werefoundmoderateand $19.23 \%$ werefoundsevere ondepression. 
Level of Life Satisfaction of the Respondents Table 3

\begin{tabular}{|l|l|l|l|}
\hline Score & Life Satisfaction & Frequency & Percentage (\%) \\
\hline $10-14$ & Dissatisfied & 8 & 4.00 \\
\hline $15-19$ & Slightly Dissatisfied & 33 & 16.50 \\
\hline 20 & Neutral & 8 & 4.00 \\
\hline $21-25$ & Slightly Satisfied & 58 & 29.00 \\
\hline $26-30$ & Satisfied & 81 & 40.50 \\
\hline $31-35$ & Extremely Satisfied & 12 & 6.00 \\
\hline Total & $\mathbf{2 0 0}$ & $\mathbf{1 0 0 . 0 0}$ \\
\hline
\end{tabular}

Table 3 shows that most of the respondents were classified as having a satisfied life satisfaction, making up 40.50 percent of the population. It was followed by respondentsstatingthattheyareslightlysatisfiedaspertheirjudgementoftheirlivesand 33 were classified as slightly dissatisfied making up 16.50 percent of the respondents. Thissuggeststhatmostfillennialstudents'currentlifesituationandinternalizedstandards are positive as per their assessment. According to Shanza and Karim (2014), life satisfaction is an overall assessment of ones' life that could range from positive or negative. Data dictates that most fillennial students have positive life satisfaction that suggest they value non-material things more than that material things and that they are more engaged socially with friend andfamily.

Relating Addiction, Depression and Life Satisfaction

Table 4

\begin{tabular}{|c|c|c|c|c|}
\hline \multirow{3}{*}{ Depression } & \multicolumn{4}{|c|}{ Internet Addiction } \\
\hline & $\begin{array}{l}\text { Pearson } \\
\text { Coefficient }\end{array}$ & p-value & Decision & Remarks \\
\hline & 0.243 & 0.001 & Reject Ho & Significant \\
\hline Life Satisfaction & -0.012 & 0.866 & Accept Ho & Not Significant \\
\hline
\end{tabular}

Note:Ifpvalueislessthanorequaltothelevelofsignificancewhichis

0.05rejectthenullhypothesisotherwiseaccept.Correlationcoefficientvalues:

$\pm 0.76- \pm 0.99$ Very Strong; $\pm 0.51- \pm 0.75$ Strong; $\pm 0.26- \pm 0.50$ Moderate; \pm 0.11

- \pm 0.25 Weak; $\pm 0.01- \pm 0.10$ Very Weak.

Table 4 presents the relationship between the respondents' internet addiction and level of depression. Since the value of pearson coefficient is .243 has a p-value of 0.001 theoccurrence ofdepressionhascorrelation,thenthecomputedvaluesarefoundtohave a positively weak significance. This suggests that the more a respondent is addicted, the more the depression is present. This exhibits same results of studies of Baht and colleagues (2015), which reveals that there is a significant positive correlation $\left(r=.809^{*}, p=<0.001\right)$ between internet addiction and depression among university students, indicating "further the internet addiction the depression as well, and less the internet addiction,lessisthedepression."MoreverwithGoel,Subramanyam\&Kamath(2013)as 0.7\% were found to be addicts. Those with excessive use internet had high scores on anxiety and depression. Lastly, Akin and Iskanders study (2011) study which lends support to the strength of correlation in their study that upon using correlation analysis, internetaddictionwasfoundpositivelyrelatedtodepression $(\mathrm{r}=.67, \mathrm{p}<.01)$. Thisresearch shows that internet addiction 
has a direct impact on depression, and that students high in internet addiction are more likely vulnerable todepression.

On relationship between the respondents' internet addiction and level of Life satisfaction, Pearson coefficient $\begin{array}{llllllll}\text { value of } & -0.012 & \text { has } & \text { a } & p \text {-value } & \text { of } & 0.866 & \text { the }\end{array}$ occurrenceofinternetaddictiontowardslifesatisfactionsuggestthatthereisnoornegativelyveryweak correlation, then the computed values are found to be not significant, failing to reject the null hypothesis. Therefore, we can infer that internet addiction has no correlation to life satisfaction. Contrary to the results were reported in the study of Shanza and Karim (2014), Internet addiction has significant and negative impact on both life satisfaction(B

$=-.168, \mathrm{p}<.001)$ andlifeengagement $(\mathrm{B}=-.066, \mathrm{p}<.05)$. Thefindingsalsooppositethose of Cao, Sun, Wan, Hao\& Tao (2011), who found out that Internet Addiction was seen to alsohaveaneffectonone'slifesatisfaction. Thestudy'sresultsmightbeduetodifferent living conditions of those in the rural area, as rural areas tend to be connected more physically than online and fellowship are still done the old fashioned way. Further, electric supply might also intervene in the time spentonline.

\section{Discussion}

Thisstudyexploredontherelationshipofinternetaddictiontowardsdepressionand

lifesatisfactioninthePhilippinesparticularlyinaStateUniversitylocatedinaruralarea. There are very few of these studies and those existing are focused on urban areas. It specifically sought to answer the level of Internet Addiction of the respondents, level of depression and level of Life Satisfaction. Moreover, the study explored the significant relationship between Internet addiction towards depression and life satisfaction. For Internet Addiction, most fillennial respondents spend have average level internet addiction.ThismaybesoasInternethasbecomeanintegralpartofourwayoflivingand although the Average users can still control their usage, cooperative efforts from school and the family will do well to monitor these Average users to prevent becoming problematic users. As for the excessive users, immediate intervention should be done as aspects of their lives are already affected by spending too much time on the internet. Though few in numbers, this shows that extreme cases are existing even in rural areas prompting the University to look into policies on internet use. As for the level of Depression, although respondents with mild depression may not need serious treatment, they should watch out for their psychological well-being. And those severe cases needs treatmentimmediatelyandshouldbeseeingaspecialist.Havingthesedata,theUniversity should revisit its policy in promoting a conducive environment and teaching strategies involving the use of internet as respondents with mild depression might worsen andthat

the University should be capable to at least provide mental first aid for those with severe level depression and have linkages for specialist capable of address these concerns for referrals.FortheirlevelofLifeSatisfaction,mostfillennialstudents'currentlifesituation andinternalizedstandardsare satisfiedaspertheirassessment.Butsomearedissatisfied. Results provide further exploration on the areas of life satisfaction as the University can identify which aspects or ways could be continued leading to increased life satisfaction, andthosecontributingtodissatisfactioncouldbeimproved.Fortherelationshipbetween Internet Addiction and Life satisfaction, results show having a positively weak relationship, this suggests that the more the respondent has addiction, the more thedepression.Havingestablishedthisresults,itispertinenttoregulatetheuseandproper utilization of the internet as a tool for learning and socializing. Too much and unguided use risk the user not just to addiction, but depression as well, that when untreated might lead to severe psychological disorders. Lastly, there is no or negatively very weak relationship between internet addiction and life satisfaction. Results might be due to different living conditions of those in the rural area, as rural areas tend to be connected more physically than online and fellowship are still done the old fashioned way. Further, electric supply might also intervene in the time spentonline.

\section{Conclusion}

Based on the findings, the researcher arrived at the following conclusions; Most of respondents were classified as average level users with internet addiction while some were problematic level users. Half of the respondents were subject to mild depression whileotherswereidentifiedasundergoingmoderatedepression.Mostoftherespondents aresatisfiedwiththeirlivesbutleastaredissatisfied.Finally,therewasanevidentpositive significant relationship between internet addiction and depression and there is no or negatively weak relationship between internet addiction and lifesatisfaction.

Thereforeitisrecommendedtoraiseawarenessofinternetusagetowardsstudents as this could greatly affect their personal relationships and academic performance. Parents,teachers, andcounselorsshouldworkhand-inhandtoproperlyuseofinternetto prevent problems in the future. Proper regulation on the part of parents 
especiallyshould be practiced. Internet providers should also come up with regulations and parameters basedonusersprofiletopreventexposuretoundesirableandsensitivecontentforcertain

demographics without suppressing learning experience. Inculcating the proper use of internet and monitor time usage could be done. Those identified with internet addiction and depression should be encouraged to avail of counseling and psychological services of the university, as contents seen in the virtual world could cause confusion and sway students from the right path of development. Philippine government should look into similarcasesforpreventionanduseasbasisforcraftingpoliciesorlawsfortherightuse of Internet. Lastly, respondents can continue with the overall life style that contribute to satisfaction, and work on those areas that need to be improved to promote a better life satisfaction lessening negativity and undesired possible effects of theweb.

\section{Conflict of Interest}

I certify that there is no conflict of interest with any financial, personal, or other relationships with other people or organization related to the material discussed in the manuscript.

\section{Acknowledgements}

The author would like to warmly expresses his gratitude and acknowledgement to all individuals who have made the conduct of the study possible. He is indebted to all researchers and scholars whose works were cited herein. Likewise, he would like to express his gratitude to the developers of the research instrument, especially the International Society of Internet Addiction. To the institutions who permitted data collection, the mentors and colleague for the support and to his Family and Wife.

\section{References}

Ardales B.V(2008). Basic Concepts and methods in Research. Educational Publishing House

Feist J. and Feist G. (2009). Theories of Personality, 7th Edition.

Hair, J.F., Black, W.C., Babin, B.J. and Anderson, R.E. (2009) Multivariate Data Analysis (7th Edition) New Jersey: Prentice-Hall, Inc.

Kothari, C.R (2004) Research Methodology: Methods and Technique New Age International (p) Limited, Publishers.

Jurnal The Messenger, Vol. ..., No. ..., January or July 20.., pp. ...-...

Neukrug, E. (2014). Counseling Theory and Practice, 1st Edition.

Journals and Monographs

Akin, A. \& Iskander, M., (2011). Internet Addiction and Depression, Anxiety and Stress. International Online Journal of Educational Sciences. 3(1), 138-

148

Baht, S. \& Kawa, H. (2015). A Study of Internet Addiction and Depression among University Students. Int J Behav Res Psychol, 3(4), 105-108.

Bastani, S. (2008). Gender Division in Computer and Internet Application: Investigation of the Students of Tehran Universities. Women Studies, 5,

45-64.

Block, J. J. (2008). Issues for DSM-V: Internet addiction. American Journal of Psychiatry, 165, 306-307.

Bringula, R., Bonifacio, J., Natanauna, A., Manuel M., \& Panganiban, K. (2012). Pattern of Internet Usage in Cyber Cafes in Manila: An Exploratory Study. International Journal of Cyber Society and Education. 5 (2) 149-162

Burnay, J., Billieux, J., Blairy, S. \& Larøi, F. (2015). Which psychological factors influence Internet addiction? Evidence through an integrative model Computers in Human Behavior. 43 28-34

Cao, H., Sun, Y., Wan, Y., Hao, J., \& Tao, F. (2011). Problematic Internet use in Chinese adolescents and its relation to psychosomatic symptoms and life satisfaction. BMC Public Health 10.1186/1471-2458-11-802

Datu, J. A., Valdez, J. P. \& Datu, N. (2012). Does Facebooking make us sad?

Hunting relationship between Facebook use and depression among Filipino adolescents. International Journal of Research Studies in Educational Technology 1 (2) 83-91

Gentile, D. A., Choo, H., Liau, A., Sim, T., Li, D., Fung, D., et al. (2011).

Pathologicalvideo game use among youths: A two-year longitudinal study.

Pediatrics, 127, 319329.

Kuss, D. J., Griffiths, M. D., Karila, L., \& Billieux, J. (2014). Internet addiction: A

literature review of epidemiological research for the last decade. Current Pharmaceutical Design, 20, 4026-4052.

Mak, K, Lai, C., Watanabe H., Kim, D., Bahar,, N., Ramos M., Young, K., Ho, R.,

Title of Paper ... (First Author)

2810

Aum, N. \& Cheng, C. (2014). Epidemiology of Internet Behaviors and Addiction Among Adolescents in Six Asian Countries. CYBERPSYCHOLOGY, BEHAVIOR, AND SOCIAL NETWORKING. 17 (11) 
Sahin, C. (2016). Examination of the Relationship between Life Satisfaction Level and Internet Addiction of the Students in Guidance and Psychological Counseling Department. International Journal of Contemporary Educational Studies 2 (1) 2548-9373

Shanaz, I \& Karim, A. (2014). The Impact of Internet Addiction on Life Satisfaction and Life Engagement in Young Adults. Universal Journal of Psychology 2(9): 273-284

Simek, E. \& Sali, J (2014), The Role of Internet Addiction and Social Media Membership University Students' Psychological Capital CONTEMPORARY EDUCATIONAL TECHNOLOGY, 2014, 5(3), 239-

256

Subramaniam, M., Shijia, Q. and M. Winslow, 2008. Prevalence and correlas of Excessive internet use among youth in Singapore. Annals Academy of Medicine, 37(1): 10 -14.

Zainudin, A., Din, M., \& Othman M. (2013). IMPACTS DUE TO INTERNET ADDICTION AMONG MALAYSIAN UNIVERSITY STUDENTS.

International Journal of Asian Social Science, 3(9):1922-192

Theses/Dissertations

Cardak, M., Mustafa, C., \& Colak, T. (2009). The Effect of a Rational Emotional Behavior Therapy (REBT)

Group Counseling Program on the Internet Addiction among University Students

Hechanova, M. R \& Go, R. (2014). The Good, The Bad and The Ugly: Internet Use, Outcomes and the role of Regulation in the Philippines.

De Argaez, E., (2012). Internet World Stats. http://www.Internetworldstats.com/ consulté le 09 avril 2012.

Frangos, C. C., Frangos, C. C., \& Sotiropoulos, I. (2011). Problematic Internet Use among Greek University Students: An Ordinal Logistic Regression with Risk Factors' Negative Psychological Beliefs, Pornographic Sites and Online Games. CyberPsychology, Behavior and Social Networking: http://www.liebertonline.com

Jurnal The Messenger, Vol. ..., No. ..., January or July 20.., pp. ...-...

Gultiano, S., King, E., Orbeta, A., \& Gordoncillo, P. (2010). Internet Use among Filipino Public Highs School Students

Goel, D., Subramanyam, A. \& Kamath, R. (2013). A study on the prevalence of Internet addiction and its association with psychopathology in Indian adolescents

Hechanova, R. \& Czincz, J. (2009). Internet Addiction: Debating the Diagnosis.

Jelenchick, L. A., Eickhoff, J .C., \& Moreno, M. A. (in press). Facebook depression? Social networking site use and depression in older adolescents. Journal of Adolescent Health.

Khan, R., Salim, M., Bilal, M., Hussain, A., \& Hasseb, M. (2014). The Relationship between Internet Addiction and Anxiety among students of University of Sargodha

Kuss, D. J., Shorter, G. W., van Rooij, A. J., Griffiths, M. D., \& Schoenmakers,

T. (2013). Assessing Internet addiction using the parsimonious Internet addiction components model. A preliminary study.

Lissita, S. \& Bolotin S. (2014). Life satisfaction in the internet age e Changes in the past decade.

Pangan, J. E. (2008). Level up!, But I got to Log In!, Net Love; a collection of three shortscreenplays on computer and internet addiction.

Tokunaga, R. (2015). Perspective on Internet Addiction, Problematic Internet Use and Deficient Self-regulation

Waldo, A (2014). Correlates of Internet Addiction among Adolescents. Whisman, Jessica (2015). A Comparative Analysis of Internet Addiction and

Substance Abuse in Adolescents Abuse in Adolescents Valiputhenpurayil, M. J. (2005). Internet Addiction Among College Students

Electronic Sources

Addictionrecov.org (2017). What is internet http://www.addictionrecov.org/Addictions/index.aspx?AID=43

Abs-cbn.com (2011). How many teens have internet addiction? http://news.abs-cbn.com/lifestyle/05/20/11/howmany-teens-have- internet-addiction

Title of Paper ... (First Author)

2810

Rappler.com (2016). Profile internet users ph http://www.rappler.com/brandrap/profile-internet-users-ph

Ncbi.nlm.nih.gov (2014).Internet addiction disorder and youth https://www.ncbi.nlm.nih.gov/pmc/articles/PMC4303443/

Philstar.com (2016). Internet Addiction

http://www.philstar.com/cebu-lifestyle/2016/04/13/1572423/internet- addiction

Malaya.com (2015). Internet addiction health concern http://www.malaya.com.ph/businessnews/business/internet-addiction- health-concern

lifestyle.inquirer.net (2011). Screen life http://lifestyle.inquirer.net/2111/screen-life/ 
huffingtonpost.com (2017).Philippines: A Digital Lifestyle Capital in the Making?

http://www.huffingtonpost.com/jonha-revesencio/philippines-a-digital- lif_1_b_7199924.html

generationy20.com (2017): Uniquely Generation Z https://www.generationy20.com/retail-generation-z.PDF 